\title{
Wounding in the plant tissue: the defense of a dangerous passage
}

\section{Daniel V. Savatin, Giovanna Gramegna, Vanessa Modesti and Felice Cervone*}

Department of Biology and Biotechnology "Charles Darwin", Sapienza-University of Rome, Rome, Italy

\section{Edited by:}

Martin Heil, Centro de Investigación y de Estudios Avanzados del Instituto

Politécnico Nacional - Unidad

Irapuato, Mexico

\section{Reviewed by:}

Mario Serrano, University of Fribourg, Switzerland

Gregory Pearce, Lewis-Clark State

College, USA

\section{*Correspondence:}

Felice Cervone, Department of Biology and Biotechnology "Charles Darwin," Sapienza-University of Rome, Piazzale Aldo Moro 5, Rome 00185, Italy

e-mail: felice.cervone@uniroma1.it
Plants are continuously exposed to agents such as herbivores and environmental mechanical stresses that cause wounding and open the way to the invasion by microbial pathogens. Wounding provides nutrients to pathogens and facilitates their entry into the tissue and subsequent infection. Plants have evolved constitutive and induced defense mechanisms to properly respond to wounding and prevent infection. The constitutive defenses are represented by physical barriers, i.e., the presence of cuticle or lignin, or by metabolites that act as toxins or deterrents for herbivores. Plants are also able to sense the injured tissue as an altered self and induce responses similar to those activated by pathogen infection. Endogenous molecules released from wounded tissue may act as Damage-Associated Molecular Patterns (DAMPs) that activate the plant innate immunity. Wound-induced responses are both rapid, such as the oxidative burst and the expression of defense-related genes, and late, such as the callose deposition, the accumulation of proteinase inhibitors and of hydrolytic enzymes (i.e., chitinases and gluganases). Typical examples of DAMPs involved in the response to wounding are the peptide systemin, and the oligogalacturonides, which are oligosaccharides released from the pectic component of the cell wall. Responses to wounding take place both at the site of damage (local response) and systemically (systemic response) and are mediated by hormones such as jasmonic acid, ethylene, salicylic acid, and abscisic acid.

Keywords: wounding, oligogalacturonides, wound response, systemin, jasmonate

\section{INTRODUCTION}

The sessile condition exposes plants to any possible environmental stress. Injury, one of the most frequent stress conditions that plants must face, may cause both loss of nutrients and entry of microbes. Therefore, plants have evolved sophisticated mechanisms to promptly respond to wounding, rapidly heal the tissue and prevent microbe infections. Unlike animals, plants do not have mobile cells specialized for defense, but each plant cell has the capability to activate protective mechanisms upon injury sensing. The capacity of cells to activate defense responses upon "danger" sensing and recognition of non-self microbe-associated molecular patterns (MAMPs) and/or endogenous damage-associated molecular patterns (DAMPs) is characteristic of the plant innate immunity (Akira etal., 2006). Defense responses activated by wounding are similar and overlapping with those activated by MAMPs and DAMPs, indicating that both injury and pathogens are limited by plants in a similar manner. Most of our knowledge on wounding derives from studies in which plants are mechanically damaged. Mechanical injury activates defenses that are similar to those induced by herbivores and insects (Reymond et al., 2000; Arimura et al., 2005; Rehrig et al., 2014), although the damage caused by herbivores has peculiar characteristics and mechanical wounding is necessary but not sufficient to trigger the full response activated by insects (Maffei et al., 2007). Differences between mechanical wounding and attacks by herbivores and insects will be discussed in other reviews of this issue (Krautz et al., 2014).
Plants contrast wounding with both constitutive structures, such as epicuticular films and crystals of wax, and secretory conduits for latices or resins, that restrict the access of opportunistic microorganisms to the tissue, as well as wound-induced responses that, unlike the constitutive defenses, are energetically costly (Leon et al., 2001; Bonaventure and Baldwin, 2010) and thereby regulated and triggered only when required. The primary events of the response to wounding occur at the injured site (local response) while the undamaged tissues respond later (systemic response), upon perception of mobile signals that communicate the existence of a critical condition (Farmer and Ryan, 1992). Extracellular signals such as cell wall-derived oligogalacturonides (OGs) and peptides, like systemin, have been characterized as typical signals of wounding (Roberts, 1992). Genes involved in biosynthesis of jasmonic acid (JA) and ethylene (ET) as well as genes for general stress responses (oxidative stress, dehydration stress, heat-shock proteins, etc.) are rapidly induced (Reymond et al., 2000; Delessert et al., 2004). Later, events of protein turnover and transport processes involving aquaporins, lipid transfer proteins, ABC transporters, sugar, and peptide transporters occur. Finally, the modulation of primary metabolism (carbohydrate and lipid metabolism, nitrogen assimilation) and the expression of genes involved in the biosynthesis of secondary metabolites with repellent or anti-digestive activity [i.e., glucosinolates, cyanogenic glucosides, alkaloids, phenolics, and proteinase inhibitors (PI)] may occur. Transcriptional profiling analyses performed on 8.200 Arabidopsis genes revealed that approximately $8 \%$ of these genes 
are differential expressed after wounding and about $20 \%$ of the wounding-regulated genes encode proteins involved in signal transduction, such as members in the AP2, WRKY, and MYB families (Cheong et al., 2002). A large fraction of the woundresponsive genes are also responsive to pathogens, suggesting that signaling pathways activated by these stimuli are shared (see below). This clearly indicates that an important reprograming of gene expression occurs in plants to defend the damaged tissue, which represents an easy passage for pathogen invasion. Receptors and signal transduction elements usually involved in pathogen response as well as several putative disease resistance genes ( $R$ genes) are up-regulated by wounding (Cheong et al., 2002). This review is focused on what is currently known about the putative signals that are released upon wounding, on the mechanism of their perception and transduction and on plant defense responses activated upon injury sensing.

\section{SENSING THE WOUNDING THROUGH THE CELL WALL INTEGRITY}

The cuticle, composed of cutin and cuticular waxes, covers the outermost epidermal cell wall in the aerial portions of plants (Riederer and Schreiber, 2001; Nawrath, 2006). The integrity of cuticle and cell wall (CWI) is affected by wounding and may be sensed by the plant cells. Studies on Arabidopsis plants expressing cutinase (Sieber et al., 2000) and on mutants impaired in cuticle biosynthesis have indicated that a more permeable cuticle allows the passage of diffusates with growth-inhibiting activity against phytopathogenic fungi (Bessire et al., 2007; Chassot et al., 2007). A breach in the cuticle caused by wounding also favors the diffusion of elicitors that, therefore, have an easier access to the cell surface, while an intact cuticle may prevent their passage from the surface. An early recognition of elicitors may lead to a prompt and efficient activation of the immune responses (L'Haridon et al., 2011; Benikhlef et al., 2013).

The cell wall is a dynamic structure that play a critical role in growth and development as well as in preventing wounding and pathogen attack (Bellincampi et al., 2014). The perception of an altered CWI is a key event during wounding (Nuhse, 2012; Wolf et al., 2012). Subtle modifications caused by physical perturbations such as light touch, soft mechanical stress, wind or contact with insects may be sensed at the level of the plasma membrane through stretch-activated mechano-sensitive channels that increase the intracellular $\mathrm{Ca}^{2+}$ concentration and trigger further signal transduction events (Nakagawa et al., 2007; Haswell et al., 2008; Benikhlef et al., 2013). Expression of the Arabidopsis calcium channels MATING INDUCED DEATH 1 (MID1)-COMPLEMENTING ACTIVITY 1 (MCA1) and MCA2 in yeast complements the lethal effect of loss-of-function mutations in the MID1 and MID2 genes encoding stretch-activated calcium channels (Kanzaki et al., 1999; Ketela et al., 1999) and promote calcium influx upon mechanical stimulation (Nakagawa et al., 2007; Yamanaka et al., 2010). Putative cation channels belonging to the GLUTAMATE RECEPTOR-LIKE (GLR) family, which mediate calcium influxes in response to MAMPs (Kwaaitaal etal., 2011), are also required for the expression of several JA-inducible genes upon wounding in Arabidopsis (Mousavi et al., 2013).
Several Arabidopsis receptor like kinases (RLKs), among which those belonging to the Catharanthus roseus receptor-like kinase 1 family that includes THESEUS 1 (THE1), HERCULES 1, and FERONIA, have been proposed as possible sensors of CWI (Hematy et al., 2007; Guo et al., 2009). Loss of THE1 function attenuates the growth defects and ectopic lignification phenotype caused by a mutation in the CELLULOSE SYNTHASE 6 (Hematy et al., 2007). Moreover, THE1 is involved in the accumulation of reactive oxygen species (ROS) and lignin deposition induced by isoxaben, an inhibitor of cellulose synthesis (Denness et al., 2011). This evidence clearly shows that defects in the cell wall caused by a disturbance of cellulose biosynthesis are sensed through THE1.

The monitoring of the status of pectin contributes to the sensing of CWI alterations (De Lorenzo et al., 2011). Plants carrying mutations that significantly alter pectin integrity, such as quasimodo 2 or tumorous shoot development 2, exhibit constitutive induction of defense responses (Krupkova et al., 2007; Mouille et al., 2007). However, minor modifications in the methylation status, which occur in transgenic plants overexpressing the inhibitors of pectin methylesterases or in $\mathrm{KO}$ mutants of PECTIN METHYLESTERASE 3, do not influence the expression of defense genes (Lionetti et al., 2007, 2010, 2012; Raiola et al., 2011). Possible indicator of an altered pectin integrity is the presence of OGs, a well-known class of DAMPs that, similarly to MAMPs, act as danger signals for the activation of the immune responses (Boller and Felix, 2009; De Lorenzo et al., 2011). OGs are released from the plant cell walls upon partial degradation of homogalacturonan, the main component of pectin, by wound-induced hydrolytic enzymes or, during infections, by microbial hydrolytic enzymes. The size of OGs is critical for their elicitor activity, being OGs with a degree of polymerization (DP) between 10 and 15 most active while shorter oligomers are inactive. OGs induce in several plant species a wide range of defense responses, including production of ROS, nitric oxide, phytoalexins, glucanase, chitinase, and callose (Bellincampi et al., 2000; Galletti et al., 2008; Rasul et al., 2012; Ferrari et al., 2013). In tomato, OGs, probably generated by the action of a wound-inducible plant-derived polygalacturonase (PG; Bergey etal., 1999), induce the accumulation of PI (Ryan and Jagendorf, 1995). OGs may act only locally, because their oligoanionic nature confers them a limited mobility in the tissues (Baydoun and Fry, 1985). In Arabidopsis, both wounding and OG treatment induce a strong local resistance against the necrotrophic fungus Botrytis cinerea that is independent of salicylic acid (SA)- and JA-mediated signaling (Chassot et al., 2007; Ferrari et al., 2007). OGs also antagonize auxin responses (Branca etal., 1988; Bellincampi et al., 1996; Ferrari et al., 2008; Savatin et al., 2011), but the auxin-OG antagonism is uncoupled from their activity as defense elicitors. Indeed, the Arabidopsis mitogen-activated protein (MAP) kinase kinase kinases ANPs have been identified as elements in the OG-mediated induction of defenses, but do not play a major role in the inhibition of the auxin-induced gene expression (Savatin et al., 2014).

OG sensing in Arabidopsis may involve wall-associated kinases (WAKs; Brutus et al., 2010; Kohorn and Kohorn, 2012). WAKs are RLKs consisting of an extracellular domain, containing epidermal 
growth factor repeats, a transmembrane domain and a cytoplasmic Ser/Thr kinase domain. The extracellular domain of WAK1 and WAK2 also contains an N-terminal portion that binds pectin in vitro (Decreux and Messiaen, 2005; Kohorn et al., 2009). OGs with a DP $>9$ bind reversibly WAK1 and the binding increases when OGs are present as dimers in a calcium-mediated "egg box" conformation (Decreux and Messiaen, 2005; Cabrera et al., 2008). Five WAK genes are clustered on chromosome 1 and additional 21 WAK-like genes (WAKL) are present in Arabidopsis (Verica et al., 2003). WAK1, WAK2, WAKL5, and WAKL7 are induced by wounding (Wagner and Kohorn, 2001; Verica et al., 2003). In rice, OsWAK1 is also induced by mechanical wounding as well as by SA and methyl-JA (MeJA) but not by abscisic acid (ABA; Li et al., 2008). A role of WAK2 in the wound response was suggested by the analysis of gene expression in plants overexpressing WAK2 fused to a TAP epitope (Kohorn et al., 2012).

A lectin receptor kinase-I.9 (DORN1), which plays a role in the perception of extracellular ATP, is also involved in the wound responses. Indeed, ectopic expression of DORN1 enhances expression of genes co-regulated by wounding and ATP (Choi et al., 2014). A maize wound-induced gene encoding a leucine-rich RLK (WPK1) is involved in JA- and phytochrome-mediated signaling (He et al., 2005). In tobacco, a leucine-rich repeat RLK (WRK) is involved in the JA-dependent wound signaling and acts upstream of the SA- and wound-induced protein kinases SIPK and WIPK, respectively (Seo et al., 1995; Zhang and Klessig, 1998a,b; Takabatake et al., 2006). WRK expression increases $15 \mathrm{~min}$ after wounding (Ito et al., 2002). WRK orthologs are present in dicots (Arabidopsis and tomato) but not in monocots (rice and wheat; Takabatake et al., 2006).

\section{WOUND-ASSOCIATED DAMPS}

Peptides that function as DAMPs have been isolated in wounded tissues. Systemin, a 18-aminoacid peptide, was identified in tomato after wounding or insect attack as a cleavage product released into the apoplast from prosystemin, i.e., a larger cytoplasmic precursor protein that accumulates in the cytosol of phloem parenchyma cells (Jacinto et al., 1997; Narvaez-Vasquez and Ryan, 2004; Schilmiller and Howe, 2005). Sensing of systemin activates the biosynthesis of JA, which, in turn, activates defenses responses in neighboring cells (Orozco-Cardenas et al., 1993). The systemin receptor was identified as the tomato homolog of the brassinosteroid receptor BRI1, SR160 (Scheer and Ryan, 1999), but more recent findings argued against this evidence (Hind et al., 2010). Hydroxyproline-rich systemins (HypSys) that trigger plant immunity during herbivore or pathogen attack (Heiling et al., 2010; Bhattacharya etal., 2013) have been identified in Solanaceae (Pearce et al., 2001, 2007, 2009; Pearce and Ryan, 2003; Bhattacharya et al., 2013) and in sweet potato (Chen et al., 2008). HypSys peptides, as systemin, are processed from precursor proteins which are induced by wounding (Narvaez-Vasquez et al., 2005).

A peptide, Pep1, was identified in Arabidopsis for its capability of inducing alkalinization in suspension-cultured cells. Pep1 is a 23-amino acid peptide released from the C-terminus of a 92 amino acid precursor protein, PROPEP1, which is induced by wounding, MeJA and ET. PROPEP1 belongs to a gene family of eight members. The family members PROPEP2 and PROPEP 3 , and, to a lesser extent, PROPEP1 are strongly induced by microbial pathogens such as B. cinerea, Phytophthora infestans, and Pseudomonas syringae as well as by various MAMPs and DAMPs elicitors, including NPP1, HrpZ, flg22, and OGs (Craigon etal., 2004; Toufighi et al., 2005; Denoux et al., 2008). PROPEPs are localized in the cytosol and the tonoplast and may function in the amplification/modulation of elicitortriggered responses rather than being signals responsible for the initiation of the defense responses (Huffaker etal., 2006; Bartels et al., 2013). Homologues of AtPeps have been identified in maize. ZmPep1 regulates disease responses whereas ZmPep3 triggers the biosynthesis of JA and ET and induces the production of anti-herbivore volatiles (Huffaker et al., 2011, 2013). AtPeps are perceived by two RLKs (PEPR1 and PEPR2), which share structural and functional similarity to the MAMP receptors FLS2 and EFR (Yamaguchi et al., 2006; Krol et al., 2010). PEPR1 and PEPR2 are induced by wounding and MeJA but not by SA and 1-aminocyclopropane-1-carboxylic acid (ACC) synthase (Yamaguchi et al., 2010). They are also differentially induced by DAMPs (AtPeps and OGs) and MAMP (flg22 and elf18; Zipfel etal., 2004, 2006; Denoux etal., 2008; Yamaguchi etal., 2010).

Cutin monomers, that are formed as a breakdown of the cuticle, have been proposed as signal molecules for the induction of disease resistance in cereals, i.e., barley and rice (Schweizer et al., 1994). Fungal pathogens such as Erysiphe graminis and Magnaporthe grisea are able to produce and secrete cutinases that facilitate the formation of cutin monomers in the infection site. Pretreated barley leaves with cutin monomers display acquired protection against E. graminis (Schweizer et al., 1996b) and evidences that free cutin monomers can be recognized by plant cells as endogenous stress-related signals were obtained in cultured potato cells (Schweizer et al., 1996a).

\section{SIGNAL TRANSDUCTION UPON WOUNDING}

Many events triggered by wounding have been uncovered and are discussed here.

\section{ELECTRIC SIGNALS}

The involvement of electrical signals in the local and systemic alert in plants was postulated in 1992, when it was found that mechanical wounding in tomato cotyledons causes the transmission of a potential action to the first unwounded leaf concomitantly with the induction of PI proteins at the site of injury (Wildon et al., 1992). More recently, it has been shown that mechanical wounding at the tips of Arabidopsis leaves generates, within a few seconds, wound-activated surface potential (WASP) changes that are consequent to a plasma membrane depolarization. The WASP signal first moves from tips toward the center of the rosette leaves and then to a restricted and selected number of distal leaves. For example, wounding at the tip of leaf no. 8 causes WASP changes of the same amplitude and duration in leaves no. 5, 11, 13, and 16 but not in other leaves. Both JA and JA-responsive gene expression increases with a total of 313 genes up-regulated both locally and systemically. GLR proteins, putative cation channels, are required for WASP propagation 
leading to defense gene expression (Mousavi et al., 2013). Similar WASP effects on JA levels and defense gene expression have been reported in tomato plants upon wounding (Herde et al., 1996). Electric signals that propagate over distances of $100 \mathrm{~cm}$ from the wounded site are generated in avocado trees (Oyarce and Gurovich, 2011).

\section{ION FLUXES}

One of the earliest responses $(0.5-2 \mathrm{~min})$ activated by the elicitors of plant defenses is the membrane depolarization following the influx of $\mathrm{H}^{+}$and $\mathrm{Ca}^{2+}$ and a concomitant efflux of $\mathrm{K}^{+}$and nitrate across the membrane (Nurnberger et al., 2004; Mithofer et al., 2005). Injury-induced ion fluxes occur in both dicots such as Vicia faba and monocots such as Hordeum vulgare (Zimmermann etal., 2009). Calcium spikes are critical for downstream signaling, since the physiological concentration of cytosolic calcium very rapidly increases after "danger" sensing (Lecourieux et al., 2006; Kudla et al., 2010; Reddy et al., 2011). In plants, as in animals, calcium is a well-known second messenger. Plants discriminate among the various stimuli by generating "calcium signatures" that are characteristic in terms of sub-cellular localization, amplitude, duration and frequency (Sanders et al., 2002). Intracellular peaks of calcium are detected in both epidermis and vascular cells proximal to the injury within $6 \mathrm{~s}$ (Beneloujaephajri et al., 2013). Signatures are decoded by three major types of sensor proteins: calmodulins (CAMs) and CAM-like proteins, calcineurin B-like proteins $(\mathrm{CBL})$ and calcium-dependent protein kinases (CDPKs), a class of calcium sensors bearing both protein kinase and CAM-like domains in a single polypeptide (Luan et al., 2002; Harper and Harmon, 2005; Luan, 2009). Different studies highlight the role of calcium sensors in plant immunity. For example, the Arabidopsis CAM binding protein (CBP) $60 \mathrm{~g}$ contributes to flg22-induced accumulation of SA and is involved in resistance against $P$. syringae (Wang et al., 2009); the rice CBL-interacting protein kinases (CIPKs) 14 and 15 are involved in various MAMPinduced immune responses (Kurusu et al., 2010); the potato and tobacco CDPKs participate in the activation of the oxidative burst (Ludwig et al., 2005; Kobayashi et al., 2007, 2012). In Arabidopsis, CALCIUM-DEPENDENT PROTEIN KINASE 3 (CPK3) and CPK13 are required for defense gene induction upon feeding by the generalist herbivore Spodoptera littoralis (Kanchiswamy et al., 2010). CPK3 is also activated by flg22 in Arabidopsis protoplasts suggesting that it is involved in MAMP signaling as well (Boudsocq et al., 2010). In tomato, LeCDPK2 contributes to wound-triggered ET production by phosphorylating and activating the ET biosynthesis enzyme ACC SYNTHASE 2 (Kamiyoshihara et al., 2010). In Nicotiana attenuata, CDPK4 and CDPK5 are negative regulators of JA synthesis; plants with silenced expression of these two CDPKs are more resistant to larvae of Manduca sexta and exhibit enhanced responses to mechanical wounding (Yang et al., 2012). MeJA, touching and mechanical wounding enhance a calciumactivated CDPK activity that induces systemic wound responses also in maize (Szczegielniak et al., 2012).

\section{REACTIVE OXYGEN SPECIES}

The production of ROS is a highly conserved process among aerobic organisms and is involved in defense and development processes of plants. ROS are emerging as signal molecules in plant immunity activation in response to both pathogens and wounding (Mittler et al., 2011; Suzuki and Mittler, 2012). In tomato, hydrogen peroxide is detected within $1 \mathrm{~h}$ after wounding and increases at 4-6 h both locally and in the upper unwounded leaves. OGs generated by a plant PG probably act as mediators of this process. A tomato mutant unable to properly respond to wounding neither induce PG nor generates hydrogen peroxide and is more susceptible to larvae of Manduca sexta (Orozco-Cardenas and Ryan, 1999). Given its toxicity, hydrogen peroxide must be tightly regulated to work as a signal molecule, and this is achieved through a complex mechanism involving calcium, protein phosphorylation, and production of ROS-scavenging enzymes that determine its steady-state levels in the cell. Wound-induced apoplastic hydrogen peroxide is produced by transmembrane NADPH oxidases (RBOHs) and by peroxidases, which also have a role in detoxification of other ROS (Minibayeva et al., 2014). The C-terminal region of plant RBOHs contains cytosolic FAD- and NADPH-binding domains and six conserved transmembrane domains while the cytosolic N-terminal region contains two EF-hand motifs which bind calcium (Kobayashi et al., 2007; Oda et al., 2010; Proels et al., 2010; Kimura et al., 2012; Drerup et al., 2013). Indeed, the wound-induced oxidative burst is dependent on calcium spikes and occurs also in the absence of the stimulus through artificially increasing the calcium levels in the cells (Monshausen et al., 2007; Takeda etal., 2008; Kimura etal., 2012). On the other hand, wound-related production of hydrogen peroxide is abolished by pretreatments with the calcium channel blocker verapamil or calcium chelators EGTA and oxalate (Beneloujaephajri et al., 2013). A calcium-dependent protein kinase CPK5 phosphorylates RBOHD and, probably, represents the link between calcium accumulation and ROS production. CPK5 phosphorylates in vitro and in vivo the N-terminal serine residues S39, S148, S163, and S347 of AtRBOHD (Dubiella et al., 2013) while, in a contradicting report, ROS production triggered by pathogen infection is reduced in $c p k 1 c p k 2$ double mutant plants (Gao et al., 2013). RBOHD forms complexes with EFR and FLS2 as well as with the plasma membrane-associated kinase BOTRYTISINDUCED KINASE 1 (BIK1), which is also required for the protection conferred by wounding against pathogens (Laluk et al., 2011). BIK1 directly interacts with and phosphorylates different residues of RBOHD in response to elicitors (Kadota et al., 2014). In addition, RBOHF activity is regulated both through direct binding of $\mathrm{Ca}^{2+}$ to EF-hands and through calcium-dependent phosphorylation by CBL1/9-CIPK26 complexes (Drerup et al., 2013).

\section{MITOGEN-ACTIVATED PROTEIN KINASES (MAPKs)}

Mitogen-activated protein kinase cascades amplify several abiotic and biotic stimuli leading to appropriate physiological responses (Rodriguez et al., 2010). They consist of a core module of three kinases that perform sequential phosphorylation reactions: a MAP kinase kinase kinase (MAP3K) activates a MAP kinase kinase (MAP2K), which activates a MAPK. Involvement of MAPKs in wounding has been widely described in various plant species (Nakagami et al., 2005). In Arabidopsis, wounding activates MEKK1, MPK3, MPK19 and, consequently, MEKK1 
phosphorylates MKK1 (Hadiarto et al., 2006). Wounding also activates MPK4 and MPK6 and plants overexpressing the PP2Ctype phosphatase $\mathrm{AP} 2 \mathrm{C} 1$, which dephosphorylates and inactivates MPK4 and MPK6, do not respond to wounding (Ichimura et al., 2000). On the contrary, ap2c1 mutants display enhanced responses to wounding and are more resistant to phytophagous mites (Tetranychus urticae; Schweighofer et al., 2007). On the other hand, MPK8, which is activated through direct binding of CAMs in a $\mathrm{Ca}^{2+}$-dependent manner and through a MKK3-mediated phosphorylation, negatively regulate the expression of RBOHD and ROS homeostasis triggered by wounding (Nemoto et al., 2011). In tobacco, the SA-induced protein kinase kinase SIPKK and MPK4, which are orthologs of Arabidopsis MKK1/MKK2 and MPK4, respectively, are required for wound-induced expression of JAresponsive genes, being MPK4 activated by SIPKK (Gomi et al., 2005). Moreover, WIPK and SIPK, which are orthologs of the Arabidopsis MPK3 and MPK6, respectively, are also involved in wounding signaling (Seo et al., 2007).

\section{HORMONES}

Wounding induces de novo synthesis of JA, ABA, and ET, which are known to activate a network of interconnected pathways that coordinate host defense responses (Peña-Cortés et al., 1995; Bergey etal., 1996; Bouquin et al., 1997). JA accumulates in wounded plants and activates expression of various defense genes such as those encoding PI, thionin, and enzymes involved in secondary metabolism (Creelman and Mullet, 1997). Jasmonates, including the active form jasmonoyl-isoleucine (JA-Ile), derive from plastidial fatty acids through at least 10 intermediates and the involvement of three cellular compartments (Staswick and Tiryaki, 2004; Browse, 2009; Fonseca etal., 2009; Schaller and Stintzi, 2009). In Arabidopsis, wounding at leaf no. 8 promptly (90 s) induces an increase of JA amount in leaf no. 13, which shares a connected vasculature with leaf no. 8 (Dengler and Kang, 2001). Plant 13-lipoxygenases (13-LOXs) catalyze the first event in JA synthesis, i.e., the dioxygenation of fatty acids (Andreou and Feussner, 2009). In Arabidopsis, LOX2 is required for the JA synthesis proximal to the wound (Glauser et al., 2009) while LOX6 is required for JA and JA-Ile accumulation in the wounded as well as in the distal unwounded leaves. The conversion of JA to JA-Ile takes $50 \mathrm{~s}$ in the wounded leaf and about $100 \mathrm{~s}$ in the distal connected leaf no. 13 (Chauvin et al., 2013). JA and JA-Ile accumulation in response to wounding have been demonstrated to be dependent on WASPs (see above, Mousavi et al., 2013). Another important step in JA synthesis is the accumulation of the JA precursor 12-oxo-phytodienoic acid (OPDA) catalyzed by allene oxidase (AOS), which is induced by tissue injury (Leon et al., 2001). In potato, two putative AOS genes, StAOS1 and StAOS2, are differentially induced upon wounding and are required for OPDA and JA accumulation both in wounded and in unchallenged tissues (Taurino et al., 2014). A possible link between JA signaling and CWI alterations is suggested by the analysis of the Arabidopsis cev1 and cob mutants, which have defects in cellulose synthesis and deposition and produce higher amount of JAs (Ellis et al., 2002; Ko et al., 2006). On the other hand, plants with a reduced expression of StAOS1 and StAOS2, and, consequently, a lower amount of OPDA, display reduced PME activity, increased methyl esterification level of pectins and an increased susceptibility to an hypovirulent strain of Dickeya dadantii (Taurino et al., 2014). In tomato, JA is preferentially generated in vascular bundles and accumulates in the midrib of leaves (Stenzel et al., 2003). AOS and lipoxygenases are located in the companion-cell-sieve-element complex of the vascular bundle (Hause etal., 2003). Since systemin accumulates in phloem parenchyma cells (Narvaez-Vasquez and Ryan, 2004) and activates the octadecanoid pathway for JA biosynthesis, it may be hypothesized that perception of systemin on the surface of companion cells initiates the synthesis of JA that is rapidly transported along the phloem (Schilmiller and Howe, 2005).

Abscisic acid is a stress hormone that mediates plant responses to drought and salinity (Finkelstein, 2013) as well as the expression of wound-induced PROTEINASE INHIBITOR II (PIN2) gene in tomato and potato (Peña-Cortés et al., 1995). Moreover, ABA positively regulates programmed death in Arabidopsis leaf cells surrounding the wounding site to confine injury and/or pathogen infections (Bostock and Stermer, 1989). Spreading of programmed cell death from wounded sites is repressed by the transcription factor MYB108 or BOTRYTIS SENSITIVE1 (BOS1; Mengiste et al., 2003), and plants lacking this element exhibit mis-regulated cell death after wounding (Cui et al., 2013).

Ethylene production upon wounding has been documented (O’Donnell et al., 1996; Bouquin et al., 1997; Liu et al., 1997). Among the early wound-induced genes there are several ACC synthase genes and many of ET response transcription factors, i.e., EREBPs (Cheong et al., 2002). In tomato, ET and wound signaling, mediated by systemin and JA, have been reported to independently act on resistance against $B$. cinerea (Diaz et al., 2002). ET and JA, besides mediating inducible defenses in response to wounding, have been also proposed to function in the tradeoff between growth and defense and the associated changes in resource allocations (Onkokesung et al., 2010).

\section{LATE RESPONSES}

Early intra- and inter-cellular events activated around the wounded site are required for late responses such as deposition of callose, suberin, lignin, and synthesis of various phenolics that may function both as a physical barrier and as antimicrobial substances. An Arabidopsis callose synthase, PMR4, is required for wound-induced callose formation (Jacobs et al., 2003). Callose is a $(1 \longrightarrow 3)-\beta$-D-glucan synthetized in all types of plant tissues in response to wounding (Chen and Kim, 2009). Its accumulation is dependent on the oxidative burst (Daudi et al., 2012; O'Brien et al., 2012) and occurs at the level of the cell wall either at wounded penetration sites or during attempted infections of fungi (Bellincampi etal., 2014). Callose may also prevent the spread of viruses through plasmodesmata (Benitez-Alfonso et al., 2011). Activity of both copper amine oxidases $(\mathrm{CuAO})$ and flavin-containing amine oxidases (PAO), hydrogen peroxide-producing enzymes responsible for the oxidative de-amination of polyamines, appears to be important in wound healing in tobacco plants (Tisi et al., 2008). CuAO mediates also the enhanced accumulation of cell wall phenolics, observed on wound surface in tobacco plants over-expressing a fungal endopolygalacturonase, which show constitutively activated defenses. This observation suggests an 


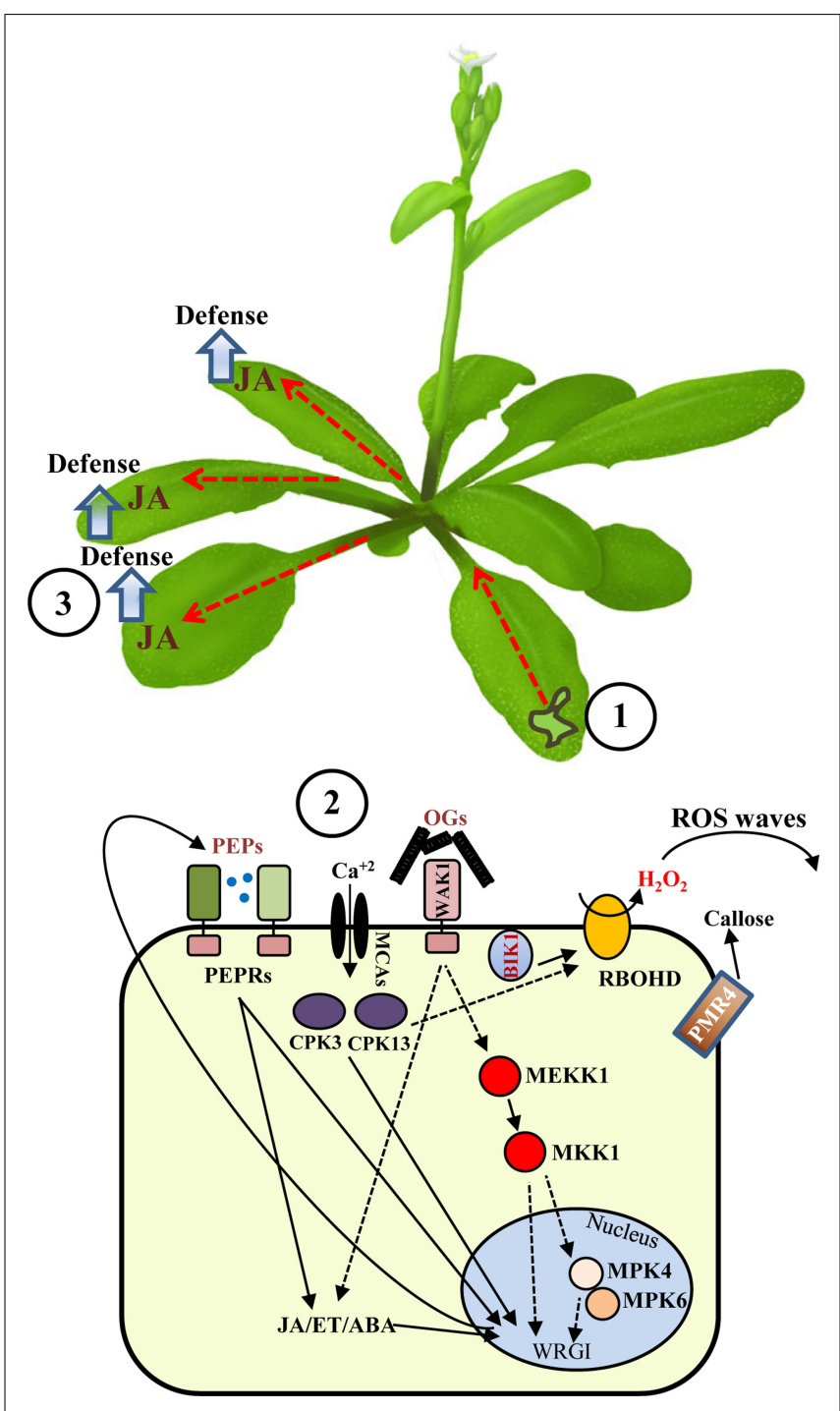

FIGURE 1 | Local and systemic responses induced by wounding in Arabidopsis. Wounding of Arabidopsis leaves (1) is sensed through mechano-sensitive elements or by recognition of damage-associate molecular patterns, such as OGs or PEPs, which are perceived at the plasma membrane level. (2) Elements involved in wound signaling include calcium channels, MAPK cascades, CDPKs, and other kinases. Cell-to-cell communication is achieved by $\mathrm{H}_{2} \mathrm{O}_{2}$ waves produced by the trans-membrane NADPH oxidase RBOHD. Alert messages are generated and systemically propagated to undamage tissues through WASPs (red dashed lines) and other signals, such as JA. (3) Dashed lines indicate still partially uncharacterized roles of MAPKs or hypothetical cascades. WRGI: wound-regulated gene induction.

important role of polyamine catabolism-derived hydrogen peroxide in the response activated by a compromised pectin integrity (Cona et al., 2014). Reconstruction of damaged tissues often takes place upon wounding and involves vascular and/or other cells that may divide and differentiate to reunite the existing tissues. Moreover, active biosynthesis and accumulation of pectic substances has been described in the cell wall of the reunion region in the cortex in cucumber and tomato hypocotyls (Asahina et al., 2002). The transcription factors RAP2.6L and ANAC071 are induced by ET and
JA, differentially expressed around the injury site and are essential for tissue reunion of Arabidopsis wounded flowering stems (Asahina et al., 2011).

\section{CONCLUSION}

Pathogens often utilize wounded tissues for their entry into the plant. Wounding is rapidly perceived through an efficient surveillance mechanism of tissue integrity followed by cell-to-cell communication and long-distance signaling. Every cell is able to rapidly produce and propagate different alert messages, such as WASPs and ROS waves (Figure 1), which rapidly prime the rest of the plant to set up defenses against the potential danger. Propagation occurs over long distances, between different parts of the same plant and even between different individuals through volatile molecules production (Komarova et al., 2014). In the recent years several elements involved in sensing and signaling of wounding have been identified showing that the defense-related responses activated by wounding are comparable and almost overlapping with those activated after elicitor sensing. Thus, injury triggers a similar level of alert as a pathogen does, indicating that a breach in the physical barriers of the plant needs to be efficiently defended.

\section{AUTHOR CONTRIBUTIONS}

Daniel V. Savatin and Giovanna Gramegna contributed equally to the manuscript. Daniel V. Savatin, Giovanna Gramegna, and Vanessa Modesti wrote the initial draft of the manuscript. Daniel V. Savatin designed and drew (Figure 1). All authors discussed the content of the manuscript.

\section{ACKNOWLEDGMENTS}

This work was supported by the ERC (ERC_AdG_233083 grant awarded to Felice Cervone) and by the Istituto Pasteur - Fondazione Cenci-Bolognetti. We thank Prof. Giulia De Lorenzo for helpful discussions.

\section{REFERENCES}

Akira, S., Uematsu, S., and Takeuchi, O. (2006). Pathogen recognition and innate immunity. Cell 124, 783-801. doi: 10.1016/j.cell.2006.02.015

Andreou, A., and Feussner, I. (2009). Lipoxygenases - structure and reaction mechanism. Phytochemistry 70, 1504-1510. doi: 10.1016/j.phytochem.2009. 05.008

Arimura, G., Kost, C., and Boland, W. (2005). Herbivore-induced, indirect plant defenses. Biochim. Biophys. Acta 1734, 91-111. doi: 10.1016/j.bbalip.2005. 03.001

Asahina, M., Azuma, K., Pitaksaringkarn, W., Yamazaki, T., Mitsuda, N., OhmeTakagi, M., et al. (2011). Spatially selective hormonal control of RAP2.6L and ANAC071 transcription factors involved in tissue reunion in Arabidopsis. Proc. Natl. Acad. Sci. U.S.A. 108, 16128-16132. doi: 10.1073/pnas.1110443108

Asahina, M., Iwai, H., Kikuchi, A., Yamaguchi, S., Kamiya, Y., Kamada, H., et al. (2002). Gibberellin produced in the cotyledon is required for cell division during tissue reunion in the cortex of cut cucumber and tomato hypocotyls. Plant Physiol. 129, 201-210. doi: 10.1104/pp.010886

Bartels, S., Lori, M., Mbengue, M., van Verk, M., Klauser, D., Hander, T., et al. (2013). The family of Peps and their precursors in Arabidopsis: differential expression and localization but similar induction of pattern-triggered immune responses. J. Exp. Bot. 64, 5309-5321. doi: 10.1093/jxb/ert330

Baydoun, E. A. H., and Fry, S. C. (1985). The immobility of pectic substances in injured tomato leaves and its bearing on the identity of the wound hormone. Planta 165, 269-276. doi: 10.1007/BF00395050

Bellincampi, D., Cardarelli, M., Zaghi, D., Serino, G., Salvi, G., Gatz, C., et al. (1996). Oligogalacturonides prevent rhizogenesis in rol B transformed tobacco explants 
by inhibiting auxin-induced expression of the rol B gene. Plant Cell 8, 477-487. doi: 10.1105/tpc.8.3.477

Bellincampi, D., Cervone, F., and Lionetti, V. (2014). Plant cell wall dynamics and wall-related susceptibility in plant-pathogen interactions. Front. Plant Sci. 5:228. doi: $10.3389 /$ fpls. 2014.00228

Bellincampi, D., Dipierro, N., Salvi, G., Cervone, F., and De Lorenzo, G. (2000). Extracellular $\mathrm{H}_{2} \mathrm{O}_{2}$ induced by oligogalacturonides is not involved in the inhibition of the auxin-regulated rolB gene expression in tobacco leaf explants. Plant Physiol. 122, 1379-1385. doi: 10.1104/pp.122.4.1379

Beneloujaephajri, E., Costa, A., L'Haridon, F., Metraux, J. P., and Binda, M. (2013). Production of reactive oxygen species and wound-induced resistance in Arabidopsis thaliana against Botrytis cinerea are preceded and depend on a burst of calcium. BMC Plant Biol. 13:160. doi: 10.1186/1471-2229-13-160

Benikhlef, L., L'Haridon, F., Abou-Mansour, E., Serrano, M., Binda, M., Costa, A., et al. (2013). Perception of soft mechanical stress in Arabidopsis leaves activates disease resistance. BMC Plant Biol. 13:133. doi: 10.1186/1471-2229-13-133

Benitez-Alfonso, Y., Jackson, D., and Maule, A. (2011). Redox regulation of intercellular transport. Protoplasma 248, 131-140. doi: 10.1007/s00709-010-0243-4

Bergey, D. R., Howe, G. A., and Ryan, C. A. (1996). Polypeptide signaling for plant defensive genes exhibits analogies to defense signaling in animals. Proc. Natl. Acad. Sci. U.S.A. 93, 12053-12058. doi: 10.1073/pnas.93.22.12053

Bergey, D. R., Orozco-Cardenas, M., De Moura, D. S., and Ryan, C. A. (1999). A wound- and systemin-inducible polygalacturonase in tomato leaves. Proc. Natl. Acad. Sci. U.S.A. 96, 1756-1760. doi: 10.1073/pnas.96.4.1756

Bessire, M., Chassot, C., Jacquat, A. C., Humphry, M., Borel, S., Petetot, J. M., et al. (2007). A permeable cuticle in Arabidopsis leads to a strong resistance to Botryti cinerea. EMBO J. 26, 2158-2168. doi: 10.1038/sj.emboj.7601658

Bhattacharya, R., Koramutla, M. K., Negi, M., Pearce, G., and Ryan, C. A (2013). Hydroxyproline-rich glycopeptide signals in potato elicit signaling associated with defense against insects and pathogens. Plant Sci. 207, 88-97. doi: 10.1016/j.plantsci.2013.03.002

Boller, T., and Felix, G. (2009). A renaissance of elicitors: perception of microbe-associated molecular patterns and danger signals by pattern-recognition receptors. Annu. Rev. Plant Biol. 60, 379-406. doi 10.1146/annurev.arplant.57.032905.105346

Bonaventure, G., and Baldwin, I. T. (2010). Transduction of wound and herbivory signals in plastids. Commun. Integr. Biol. 3, 313-317. doi: 10.4161/cib.3.4.11834

Bostock, R. M., and Stermer, B. A. (1989). Perspectives on wound healing in resistance to pathogens. Annu. Rev. Phytopathol. 27, 343-371. doi: 10.1146/annurev.py.27.090189.002015

Boudsocq, M., Willmann, M. R., McCormack, M., Lee, H., Shan, L., He, P., et al. (2010). Differential innate immune signaling via $\mathrm{Ca}^{2+}$ sensor protein kinases. Nature 464, 418-422. doi: 10.1038/nature08794

Bouquin, T., Lasserre, E., Pradier, J., Pech, J. C., and Balague, C. (1997). Wound and ethylene induction of the ACC oxidase melon gene CM-ACO1 occurs via two direct and independent transduction pathways. Plant Mol. Biol. 35, 1029-1035. doi: 10.1023/A:1005902226054

Branca, C., De Lorenzo, G., and Cervone, F. (1988). Competitive inhibition of the auxin-induced elongation by $\alpha$-D-oligogalacturonides in pea stem segments. Physiol. Plant. 72, 499-504. doi: 10.1111/j.1399-3054.1988.tb09157.x

Browse, J. (2009). The power of mutants for investigating jasmonate biosynthesis and signaling. Phytochemistry 70, 1539-1546. doi: 10.1016/j.phytochem.2009. 08.004

Brutus, A., Sicilia, F., Macone, A., Cervone, F., and De Lorenzo, G. (2010). A domain swap approach reveals a role of the plant wall-associated kinase 1 (WAK1) as a receptor of oligogalacturonides. Proc. Natl. Acad. Sci. U.S.A. 107, 9452-9457. doi: $10.1073 /$ pnas. 1000675107

Cabrera, J. C., Boland, A., Messiaen, J., Cambier, P., and Van Cutsem, P. (2008). Egg box conformation of oligogalacturonides: the time-dependent stabilization of the elicitor-active conformation increases its biological activity. Glycobiology 18, 473-482. doi: 10.1093/glycob/cwn027

Chassot, C., Nawrath, C., and Metraux, J. P. (2007). Cuticular defects lead to full immunity to a major plant pathogen. Plant J. 49, 972-980. doi: 10.1111/j.1365313X.2006.03017.x

Chauvin, A., Caldelari, D., Wolfender, J. L., and Farmer, E. E. (2013). Four 13lipoxygenases contribute to rapid jasmonate synthesis in wounded Arabidopsis thaliana leaves: a role for lipoxygenase 6 in responses to long-distance wound signals. New Phytol. 197, 566-575. doi: 10.1111/nph.12029
Chen, X. Y., and Kim, J. Y. (2009). Callose synthesis in higher plants. Plant Signal. Behav. 4, 489-492. doi: 10.4161/psb.4.6.8359

Chen, Y. C., Siems, W. F., Pearce, G., and Ryan, C. A. (2008). Six peptide wound signals derived from a single precursor protein in Ipomoea batatas leaves activate the expression of the defense gene sporamin. J. Biol. Chem. 283, 11469-11476. doi: 10.1074/jbc.M709002200

Cheong, Y. H., Chang, H. S., Gupta, R., Wang, X., Zhu, T., and Luan, S. (2002). Transcriptional profiling reveals novel interactions between wounding, pathogen, abiotic stress, and hormonal responses in Arabidopsis. Plant Physiol. 129, 661-677. doi: 10.1104/pp.002857

Choi, J., Tanaka, K., Cao, Y. R., Qi, Y., Qiu, J., Liang, Y., et al. (2014). Identification of a plant receptor for extracellular ATP. Science 343, 290-294. doi: 10.1126/science.343.6168.290

Cona, A., Tisi, A., Ghuge, S. A., Franchi, S., De Lorenzo, G., and Angelini, R. (2014). Wound healing response and xylem differentiation in tobacco plants over-expressing a fungal endopolygalacturonase is mediated by copper amine oxidase activity. Plant Physiol. Biochem. 82, 54-65. doi: 10.1016/j.plaphy.2014. 05.004

Craigon, D. J., James, N., Okyere, J., Higgins, J., Jotham, J., and May, S. (2004). NASCArrays: a repository for microarray data generated by NASC's transcriptomics service. Nucleic Acids Res. 32, D575-D577. doi: 10.1093/nar/gkh133

Creelman, R. A., and Mullet, J. E. (1997). Biosynthesis and action of jasmonates in plants. Annu. Rev. Plant Physiol. Plant Mol. Biol. 48, 355-381. doi: 10.1146/annurev.arplant.48.1.355

Cui, F., Brosche, M., Sipari, N., Tang, S., and Overmyer, K. (2013). Regulation of ABA dependent wound induced spreading cell death by MYB108. New Phytol. 200, 634-640. doi: 10.1111/nph.12456

Daudi, A., Cheng, Z. Y., O’Brien, J. A., Mammarella, N., Khan, S., Ausubel, F. M., et al. (2012). The apoplastic oxidative burst peroxidase in Arabidopsis is a major component of pattern-triggered immunity. Plant Cell 24, 275-287. doi: 10.1105/tpc.111.093039

De Lorenzo, G., Brutus, A., Savatin, D. V., Sicilia, F., and Cervone, F. (2011). Engineering plant resistance by constructing chimeric receptors that recognize damage-associated molecular patterns (DAMPs). FEBS Lett. 585, 1521-1528. doi: 10.1016/j.febslet.2011.04.043

Decreux, A., and Messiaen, J. (2005). Wall-associated kinase WAK1 interacts with cell wall pectins in a calcium-induced conformation. Plant Cell Physiol. 46, 268-278. doi: $10.1093 / \mathrm{pcp} / \mathrm{pci026}$

Delessert, C., Wilson, I. W., Van Der, S. D., Dennis, E. S., and Dolferus, R. (2004) Spatial and temporal analysis of the local response to wounding in Arabidopsis leaves. Plant Mol. Biol. 55, 165-181. doi: 10.1007/s11103-004-0112-7

Dengler, N., and Kang, J. (2001). Vascular patterning and leaf shape. Curr. Opin. Plant Biol. 4, 50-56. doi: 10.1016/S1369-5266(00)00135-7

Denness, L., McKenna, J. F., Segonzac, C., Wormit, A., Madhou, P., Bennett, M., et al. (2011). Cell wall damage-induced lignin biosynthesis is regulated by a reactive oxygen species- and jasmonic acid-dependent process in Arabidopsis. Plant Physiol. 156, 1364-1374. doi: 10.1104/pp.111.175737

Denoux, C., Galletti, R., Mammarella, N., Gopalan, S., Werck, D., De Lorenzo, G., et al. (2008). Activation of defense response pathways by OGs and Flg22 elicitors in Arabidopsis seedlings. Mol. Plant 1, 423-445. doi: 10.1093/mp/ $\operatorname{ssn} 019$

Diaz, J., ten Have, A., and van Kan, J. A. (2002). The role of ethylene and wound signaling in resistance of tomato to Botrytis cinerea. Plant Physiol. 129, 1341-1351. doi: $10.1104 / p p .001453$

Drerup, M. M., Schlucking, K., Hashimoto, K., Manishankar, P., Steinhorst, L., Kuchitsu, K., et al. (2013). The Calcineurin B-like calcium sensors CBL1 and CBL9 together with their interacting protein kinase CIPK26 regulate the Arabidopsis NADPH oxidase RBOHF. Mol. Plant 6, 559-569. doi: 10.1093/mp/sst009

Dubiella, U., Seybold, H., Durian, G., Komander, E., Lassig, R., Witte, C. P., et al. (2013). Calcium-dependent protein kinase/NADPH oxidase activation circuit is required for rapid defense signal propagation. Proc. Natl. Acad. Sci. U.S.A. 110, 8744-8749. doi: 10.1073/pnas.1221294110

Ellis, C., Karafyllidis, I., Wasternack, C., and Turner, J. G. (2002). The Arabidopsis mutant cev1 links cell wall signaling to jasmonate and ethylene responses. Plant Cell 14, 1557-1566. doi: 10.1105/tpc.002022

Farmer, E. E., and Ryan, C. A. (1992). Octadecanoid precursors of jasmonic acid activate the synthesis of wound-inducible proteinase inhibitors. Plant Cell 4, 129-134. doi: 10.1105/tpc.4.2.129 
Ferrari, S., Galletti, R., Denoux, C., De Lorenzo, G., Ausubel, F. M., and Dewdney, J. (2007). Resistance to Botrytis cinerea induced in Arabidopsis by elicitors is independent of salicylic acid, ethylene, or jasmonate signaling but requires PHYTOALEXIN DEFICIENT3. Plant Physiol. 144, 367-379. doi: 10.1104/pp.107.095596

Ferrari, S., Galletti, R., Pontiggia, D., Manfredini, C., Lionetti, V., Bellincampi, D., et al. (2008). Transgenic expression of a fungal endo-polygalacturonase increases plant resistance to pathogens and reduces auxin sensitivity. Plant Physiol. 146 669-681. doi: 10.1104/pp.107.109686

Ferrari, S., Savatin, D. V., Sicilia, F., Gramegna, G., Cervone, F., and De Lorenzo, G. (2013). Oligogalacturonides: plant damage-associated molecular patterns and regulators of growth and development. Front. Plant Sci. 4:49. doi 10.3389/fpls.2013.00049

Finkelstein, R. (2013). Abscisic acid synthesis and response. Arabidopsis Book 11:e0166. doi: 10.1199/tab.0166

Fonseca, S., Chico, J. M., and Solano, R. (2009). The jasmonate pathway: the ligand, the receptor and the core signalling module. Curr. Opin. Plant Biol. 12, 539-547. doi: 10.1016/j.pbi.2009.07.013

Galletti, R., Denoux, C., Gambetta, S., Dewdney, J., Ausubel, F. M., De Lorenzo, G., et al. (2008). The AtrbohD-mediated oxidative burst elicited by oligogalacturonides in Arabidopsis is dispensable for the activation of defense responses effective against Botrytis cinerea. Plant Physiol. 148, 1695-1706. doi: $10.1104 /$ pp.108.127845

Gao, X. Q., Chen, X., Lin, W. W., Chen, S. X., Lu, D. P., Niu, Y. J., etal. (2013). Bifurcation of Arabidopsis NLR immune signaling via $\mathrm{Ca}^{2+}$ dependent protein kinases. PLoS Pathog. 9:e1003127. doi: 10.1371/journal.ppat. 1003127

Glauser, G., Dubugnon, L., Mousavi, S. A., Rudaz, S., Wolfender, J. L., and Farmer, E E. (2009). Velocity estimates for signal propagation leading to systemic jasmonic acid accumulation in wounded Arabidopsis. J. Biol. Chem. 284, 34506-34513. doi: 10.1074/jbc.M109.061432

Gomi, K., Ogawa, D., Katou, S., Kamada, H., Nakajima, N., Saji, H., et al. (2005). A mitogen-activated protein kinase NtMPK4 activated by SIPKK is required for jasmonic acid signaling and involved in ozone tolerance via stomatal movement in tobacco. Plant Cell Physiol. 46, 1902-1914. doi: 10.1093/pcp/pci211

Guo, H. Q., Li, L., Ye, H. X., Yu, X. F., Algreen, A., and Yin, Y. H. (2009) Three related receptor-like kinases are required for optimal cell elongation in Arabidopsis thaliana. Proc. Natl. Acad. Sci. U.S.A. 106, 7648-7653. doi: 10.1073/pnas.0812346106

Hadiarto, T., Nanmori, T., Matsuoka, D., Iwasaki, T., Sato, K., Fukami, Y., et al (2006). Activation of Arabidopsis MAPK kinase kinase (AtMEKK1) and induction of AtMEKK1-AtMEK1 pathway by wounding. Planta 223, 708-713. doi: 10.1007/s00425-005-0126-7

Harper, J. F., and Harmon, A. (2005). Plants, symbiosis and parasites: A calcium signalling connection. Nat. Rev. Mol. Cell Biol. 6, 555-566. doi: 10.1038/ nrm 1679

Haswell, E. S., Peyronnet, R., Barbier-Brygoo, H., Meyerowitz, E. M., and Frachisse, J. M. (2008). Two MscS homologs provide mechanosensitive channel activities in the Arabidopsis root. Curr. Biol. 18, 730-734. doi: 10.1016/j.cub.2008.04.039

Hause, B., Hause, G., Kutter, C., Miersch, O., and Wasternack, C. (2003). Enzymes of jasmonate biosynthesis occur in tomato sieve elements. Plant Cell Physiol. 44, 643-648. doi: 10.1093/pcp/pcg072

He, G. Z., Tarui, Y., and Iino, M. (2005). A novel receptor kinase involved in jasmonate-mediated wound and phytochrome signaling in maize coleoptiles. Plant Cell Physiol. 46, 870-883. doi: 10.1093/pcp/pci092

Heiling, S., Schuman, M. C., Schoettner, M., Mukerjee, P., Berger, B., Schneider, B., et al. (2010). Jasmonate and ppHsystemin regulate key malonylation steps in the biosynthesis of 17-hydroxygeranyllinalool diterpene glycosides, an abundant and effective direct defense against herbivores in Nicotiana attenuata. Plant Cell 22 273-292. doi: 10.1105/tpc.109.071449

Hematy, K., Sado, P. E., Van Tuinen, A., Rochange, S., Desnos, T., Balzergue S., et al. (2007). A receptor-like kinase mediates the response of Arabidopsis cells to the inhibition of cellulose synthesis. Curr. Biol. 17, 922-931. doi 10.1016/j.cub.2007.05.018

Herde, O., Atzorn, R., Fisahn, J., Wasternack, C., Willmitzer, L., and PeñaCortés, H. (1996). Localized wounding by heat initiates the accumulation of proteinase inhibitor II in abscisic acid-deficient plants by triggering jasmonic acid biosynthesis. Plant Physiol. 112, 853-860.
Hind, S. R., Malinowski, R., Yalamanchili, R., and Stratmann, J. W. (2010). Tissuetype specific systemin perception and the elusive systemin receptor. Plant Signal. Behav. 5, 42-44. doi: 10.4161/psb.5.1.10119

Huffaker, A., Dafoe, N. J., and Schmelz, E. A. (2011). ZmPep1, an ortholog of Arabidopsis elicitor peptide 1, regulates maize innate immunity and enhances disease resistance. Plant Physiol. 155, 1325-1338. doi: 10.1104/pp.110. 166710

Huffaker, A., Pearce, G., and Ryan, C. A. (2006). An endogenous peptide signal in Arabidopsis activates components of the innate immune response. Proc. Natl. Acad. Sci. U.S.A. 103, 10098-10103. doi: 10.1073/pnas.0603727103

Huffaker, A., Pearce, G., Veyrat, N., Erb, M., Turlings, T. C. J., Sartor, R., et al. (2013). Plant elicitor peptides are conserved signals regulating direct and indirect antiherbivore defense. Proc. Natl. Acad. Sci. U.S.A. 110, 5707-5712. doi: $10.1073 /$ pnas. 1214668110

Ichimura, K., Mizoguchi, T., Yoshida, R., Yuasa, T., and Shinozaki, K. (2000). Various abiotic stresses rapidly activate Arabidopsis MAP kinases ATMPK4 and ATMPK6. Plant J. 24, 655-665. doi: 10.1046/j.1365-313x.2000.00913.x

Ito, N., Takabatake, R., Seo, S., Hiraga, S., Mitsuhara, I., and Ohashi, Y. (2002) Induced expression of a temperature-sensitive leucine-rich repeat receptor-like protein kinase gene by hypersensitive cell death and wounding in tobacco plant carrying the $\mathrm{N}$ resistance gene. Plant Cell Physiol. 43, 266-274. doi: $10.1093 / \mathrm{pcp} / \mathrm{pcf031}$

Jacinto, T., McGurl, B., Franceschi, V., Delano-Freier, J., and Ryan, C. A. (1997) Tomato prosystemin promoter confers wound-inducible, vascular bundlespecific expression of the $\beta$-glucuronidase gene in transgenic tomato plants. Planta 203, 406-412. doi: 10.1007/s004250050207

Jacobs, A. K., Lipka, V., Burton, R. A., Panstruga, R., Strizhov, N., Schulze-Lefert, P., et al. (2003). An Arabidopsis callose synthase, GSL5, is required for wound and papillary callose formation. Plant Cell 15, 2503-2513. doi: 10.1105/tpc. 016097

Kadota, Y., Sklenar, J., Derbyshire, P., Stransfeld, L., Asai, S., Ntoukakis, V., et al. (2014). Direct regulation of the NADPH oxidase RBOHD by the PRRassociated kinase BIK1 during plant immunity. Mol. Cell 54, 43-55. doi: 10.1016/j.molcel.2014.02.021

Kamiyoshihara, Y., Iwata, M., Fukaya, T., Tatsuki, M., and Mori, H. (2010). Turnover of LeACS2, a wound-inducible 1-aminocyclopropane-1-carboxylic acid synthase in tomato, is regulated by phosphorylation/dephosphorylation. Plant J. 64, 140150. doi: 10.1111/j.1365-313X.2010.04316.x

Kanchiswamy, C. N., Takahashi, H., Quadro, S., Maffei, M. E., Bossi, S., Bertea, C., et al. (2010). Regulation of Arabidopsis defense responses against Spodoptera littoralis by CPK-mediated calcium signaling. BMC Plant Biol. 10:97. doi: 10.1186/1471-2229-10-97

Kanzaki, M., Nagasawa, M., Kojima, I., Sato, C., Naruse, K., Sokabe, M., et al. (1999). Molecular identification of a eukaryotic, stretch-activated nonselective cation channel. Science 285, 882-886. doi: 10.1126/science.285.5429.882

Ketela, T., Green, R., and Bussey, H. (1999). Saccharomyces cerevisiae Mid2p is a potential cell wall stress sensor and upstream activator of the PKC1-MPK1 cell integrity pathway. J. Bacteriol. 181, 3330-3340.

Kimura, S., Kaya, H., Kawarazaki, T., Hiraoka, G., Senzaki, E., Michikawa, M., et al. (2012). Protein phosphorylation is a prerequisite for the $\mathrm{Ca}^{2+}$-dependent activation of Arabidopsis NADPH oxidases and may function as a trigger for the positive feedback regulation of $\mathrm{Ca}^{2+}$ and reactive oxygen species. Biochim. Biophys. Acta 1823, 398-405. doi: 10.1016/j.bbamcr.2011.09.011

Ko, J. H., Kim, J. H., Jayanty, S. S., Howe, G. A., and Han, K. H. (2006). Loss of function of COBRA, a determinant of oriented cell expansion, invokes cellular defense responses in Arabidopsis thaliana. J. Exp. Bot. 57, 2923-2936. doi: 10.1093/jxb/erl052

Kobayashi, M., Ohura, I., Kawakita, K., Yokota, N., Fujiwara, M., Shimamoto, K., et al. (2007). Calcium-dependent protein kinases regulate the production of reactive oxygen species by potato NADPH oxidase. Plant Cell 19, 1065-1080. doi: $10.1105 /$ tpc. 106.048884

Kobayashi, M., Yoshioka, M., Asai, S., Nomura, H., Kuchimura, K., Mori, H., et al. (2012). StCDPK5 confers resistance to late blight pathogen but increases susceptibility to early blight pathogen in potato via reactive oxygen species burst. New Phytol. 196, 223-237. doi: 10.1111/j.1469-8137.2012.04226.x

Kohorn, B. D., Johansen, S., Shishido, A., Todorova, T., Martinez, R., Defeo, E., et al. (2009). Pectin activation of MAP kinase and gene expression is WAK2 dependent. Plant J. 60, 974-982. doi: 10.1111/j.1365-313X.2009.04016.x 
Kohorn, B. D., and Kohorn, S. L. (2012). The cell wall-associated kinases, WAKs, as pectin receptors. Front. Plant Sci. 3:88. doi: 10.3389/fpls.2012.00088

Kohorn, B. D., Kohorn, S. L., Todorova, T., Baptiste, G., Stansky, K., and McCullough, M. (2012). A dominant allele of Arabidopsis pectin-binding wall-associated kinase induces a stress response suppressed by MPK6 but not MPK3 mutations. Mol. Plant 5, 841-851. doi: 10.1093/mp/ssr096

Komarova, T. V., Sheshukova, E. V., and Dorokhov, Y. L. (2014). Cell wall methanol as a signal in plant immunity. Front. Plant Sci. 5:101. doi: 10.3389/fpls.2014.00101

Krautz, R., Arefin, B., and Theopold, U. (2014). Damage signals in the insect immune response. Front. Plant Sci. 5:342. doi: 10.3389/fpls.2014.00342

Krol, E., Mentzel, T., Chinchilla, D., Boller, T., Felix, G., Kemmerling, B., et al. (2010). Perception of the Arabidopsis danger signal peptide 1 involves the pattern recognition receptor AtPEPR1 and its close homologue AtPEPR2. J. Biol. Chem. 285, 13471-13479. doi: 10.1074/jbc.M109.097394

Krupkova, E., Immerzeel, P., Pauly, M., and Schmulling, T. (2007). The TUMOROUS SHOOT DEVELOPMENT2 gene of Arabidopsis encoding a putative methyltransferase is required for cell adhesion and co-ordinated plant development. Plant $J$. 50, 735-750. doi: 10.1111/j.1365-313X.2007.03123.x

Kudla, J., Batistic, O., and Hashimoto, K. (2010). Calcium signals: the lead currency of plant information processing. Plant Cell 22, 541-563. doi: 10.1105/tpc.109.072686

Kurusu, T., Hamada, J., Nokajima, H., Kitagawa, Y., Kiyoduka, M., Takahashi, A., et al. (2010). Regulation of microbe-associated molecular pattern-induced hypersensitive cell death, phytoalexin production, and defense gene expression by calcineurin B-like protein-interacting protein kinases, OsCIPK14/15, in rice cultured cells. Plant Physiol. 153, 678-692. doi: 10.1104/pp.109. 151852

Kwaaitaal, M., Huisman, R., Maintz, J., Reinstadler, A., and Panstruga, R. (2011). Ionotropic glutamate receptor (iGluR)-like channels mediate MAMPinduced calcium influx in Arabidopsis thaliana. Biochem. J. 440, 355-365. doi: 10.1042/BJ20111112

L'Haridon, F., Besson-Bard, A., Binda, M., Serrano, M., Abou-Mansour, E., Balet, F., et al. (2011). A permeable cuticle is associated with the release of reactive oxygen species and induction of innate immunity. PLoS Pathog. 7:e1002148. doi: 10.1371/journal.ppat.1002148

Laluk, K., Luo, H. L., Chai, M. F., Dhawan, R., Lai, Z. B., and Mengiste, T. (2011). Biochemical and genetic requirements for function of the immune response regulator BOTRYTIS-INDUCED KINASE1 in plant growth, ethylene signaling, and PAMP-triggered immunity in Arabidopsis. Plant Cell 23, 2831-2849. doi $10.1105 /$ tpc. 111.087122

Lecourieux, D., Ranjeva, R., and Pugin, A. (2006). Calcium in plant defense-signaling pathways. New Phytol. 171, 249-269. doi: 10.1111/j.14698137.2006.01777.x

Leon, J., Rojo, E., and Sanchez-Serrano, J. J. (2001). Wound signaling in plants. J. Exp. Bot. 52, 1-9. doi: 10.1093/jexbot/52.354.1

Li, H., Zhou, S. Y., Zhao, W. S., Su, S. C., and Peng, Y. L. (2008). A novel wallassociated receptor-like protein kinase gene, OsWAK1, plays important roles in rice blast disease resistance. Plant Mol. Biol. 69, 337-346. doi: 10.1007/s11103008-9430-5

Lionetti, V., Cervone, F., and Bellincampi, D. (2012). Methyl esterification of pectin plays a role during plant-pathogen interactions and affects plant resistance to diseases. J. Plant Physiol. 169, 1623-1630. doi: 10.1016/j.jplph.2012. 05.006

Lionetti, V., Francocci, F., Ferrari, S., Volpi, C., Bellincampi, D., Galletti, R., et al. (2010). Engineering the cell wall by reducing de-methyl-esterified homogalacturonan improves saccharification of plant tissues for bioconversion. Proc. Natl. Acad. Sci. U.S.A. 107, 616-621. doi: 10.1073/pnas.0907549107

Lionetti, V., Raiola, A., Camardella, L., Giovane, A., Obel, N., Pauly, M., et al. (2007). Overexpression of pectin methylesterase inhibitors in Arabidopsis restricts fungal infection by botrytis cinerea. Plant Physiol. 143, 1871-1880. doi: 10.1104/pp.106.090803

Liu, J. H., Lee-Tamon, S. H., and Reid, D. M. (1997). Differential and woundinducible expression of 1-aminocylopropane-1-carboxylate oxidase genes in sunflower seedlings. Plant Mol. Biol. 34, 923-933. doi: 10.1023/A:1005801420172

Luan, S. (2009). The CBL-CIPK network in plant calcium signaling. Trends Plant Sci. 14, 37-42. doi: 10.1016/j.tplants.2008.10.005

Luan, S., Kudla, J., Rodriguez-Concepcion, M., Yalovsky, S., and Gruissem, W. (2002). Calmodulins and calcineurin B-like proteins: calcium sensors for specific signal response coupling in plants. Plant Cell 14, S389-S400. doi: 10.1105/tpc.001115

Ludwig, A. A., Saitoh, H., Felix, G., Freymark, G., Miersch, O., Wasternack, C., et al. (2005). Ethylene-mediated cross-talk between calcium-dependent protein kinase and MAPK signaling controls stress responses in plants. Proc. Natl. Acad. Sci. U.S.A. 102, 10736-10741. doi: 10.1073/pnas.0502954102

Maffei, M. E., Mithofer, A., and Boland, W. (2007). Before gene expression: early events in plant-insect interaction. Trends Plant Sci. 12, 310-316. doi: 10.1016/j.tplants.2007.06.001

Mengiste, T., Chen, X., Salmeron, J., and Dietrich, R. (2003). The BOTRYTIS SUSCEPTIBLE1 gene encodes an R2R3MYB transcription factor protein that is required for biotic and abiotic stress responses in Arabidopsis. Plant Cell 15, 2551-2565. doi: 10.1105/tpc.014167

Minibayeva, F., Beckett, R. P., and Kranner, I. (2014). Roles of apoplastic peroxidases in plant response to wounding. Phytochemistry doi: 10.1016/j.phytochem.2014.06.008 [Epub ahead of print].

Mithofer, A., Ebel, J., and Felle, H. H. (2005). Cation fluxes cause plasma membrane depolarization involved in beta-glucan elicitor-signaling in soybean roots. Mol. Plant Microbe Interact. 18, 983-990. doi: 10.1094/MPMI-18-0983

Mittler, R., Vanderauwera, S., Suzuki, N., Miller, G., Tognetti, V. B., Vandepoele, K., et al. (2011). ROS signaling: the new wave? Trends Plant Sci. 16, 300-309. doi: 10.1016/j.tplants.2011.03.007

Monshausen, G. B., Bibikova, T. N., Messerli, M. A., Shi, C., and Gilroy, S. (2007). Oscillations in extracellular $\mathrm{pH}$ and reactive oxygen species modulate tip growth of Arabidopsis root hairs. Proc. Natl. Acad. Sci. U.S.A. 104, 20996-21001. doi: 10.1073/pnas.0708586104

Mouille, G., Ralet, M. C., Cavelier, C., Eland, C., Effroy, D., Hematy, K., et al. (2007). Homogalacturonan synthesis in Arabidopsis thaliana requires a Golgi-localized protein with a putative methyltransferase domain. Plant J. 50, 605-614. doi: 10.1111/j.1365-313X.2007.03086.x

Mousavi, S. A. R., Chauvin, A., Pascaud, F., Kellenberger, S., and Farmer, E. E. (2013). GLUTAMATE RECEPTOR-LIKE genes mediate leaf-to-leaf wound signalling. Nature 500, 422-426. doi: 10.1038/nature12478

Nakagami, H., Pitzschke, A., and Hirt, H. (2005). Emerging MAP kinase pathways in plant stress signalling. Trends Plant Sci. 10, 339-346. doi: 10.1016/j.tplants.2005.05.009

Nakagawa, Y., Katagiri, T., Shinozaki, K., Qi, Z., Tatsumi, H., Furuichi, T., et al. (2007). Arabidopsis plasma membrane protein crucial for $\mathrm{Ca}^{2+}$ influx and touch sensing in roots. Proc. Natl. Acad. Sci. U.S.A. 104, 3639-3644. doi: 10.1073/pnas.0607703104

Narvaez-Vasquez, J., Pearce, G., and Ryan, C. A. (2005). The plant cell wall matrix harbors a precursor of defense signaling peptides. Proc. Natl. Acad. Sci. U.S.A. 102, 12974-12977. doi: 10.1073/pnas.0505248102

Narvaez-Vasquez, J., and Ryan, C. A. (2004). The cellular localization of prosystemin: a functional role for phloem parenchyma in systemic wound signaling. Planta 218 , 360-369. doi: 10.1007/s00425-003-1115-3

Nawrath, C. (2006). Unraveling the complex network of cuticular structure and function. Curr. Opin. Plant Biol. 9, 281-287. doi: 10.1016/j.pbi.2006. 03.001

Nemoto, K., Seto, T., Takahashi, H., Nozawa, A., Seki, M., Shinozaki, K., et al. (2011). Autophosphorylation profiling of Arabidopsis protein kinases using the cell-free system. Phytochemistry 72, 1136-1144. doi: 10.1016/j.phytochem.2011. 02.029

Nuhse, T. S. (2012). Cell wall integrity signaling and innate immunity in plants. Front. Plant Sci. 3:280. doi: 10.3389/fpls.2012.00280

Nurnberger, T., Brunner, F., Kemmerling, B., and Piater, L. (2004). Innate immunity in plants and animals: striking similarities and obvious differences. Immunol. Rev. 198, 249-266. doi: 10.1111/j.0105-2896.2004.0119.x

O'Brien, J. A., Daudi, A., Butt, V. S., and Bolwell, G. P. (2012). Reactive oxygen species and their role in plant defence and cell wall metabolism. Planta 236, 765-779. doi: 10.1007/s00425-012-1696-9

O'Donnell, P. J., Calvert, C., Atzorn, R., Wasternack, C., Leyser, H. M. O., and Bowles, D. J. (1996). Ethylene as a signal mediating the wound response of tomato plants. Science 274, 1914-1917. doi: 10.1126/science.274.5294.1914

Oda, T., Hashimoto, H., Kuwabara, N., Akashi, S., Hayashi, K., Kojima, C., et al. (2010). Structure of the N-terminal regulatory domain of a plant NADPH oxidase and its functional implications. J. Biol. Chem. 285, 1435-1445. doi: 10.1074/jbc.M109.058909 
Onkokesung, N., Baldwin, I. T., and Galis, I. (2010). The role of jasmonic acid and ethylene crosstalk in direct defense of Nicotiana attenuata plants against chewing herbivores. Plant Signal. Behav. 5, 1305-1307. doi: 10.4161/psb.5.10.13124

Orozco-Cardenas, M., McGurl, B., and Ryan, C. A. (1993). Expression of an antisense prosystemin gene in tomato plants reduces resistance toward Manduca sexta larvae. Proc. Natl. Acad. Sci. U.S.A. 90, 8273-8276. doi: 10.1073/pnas.90. 17.8273

Orozco-Cardenas, M., and Ryan, C. A. (1999). Hydrogen peroxide is generated systemically in plant leaves by wounding and systemin via the octadecanoid pathway. Proc. Natl. Acad. Sci. U.S.A. 96, 6553-6655. doi: 10.1073/pnas.96. 11.6553

Oyarce, P., and Gurovich, L. (2011). Evidence for the transmission of information through electric potentials in injured avocado trees. J. Plant Physiol. 168, 103-108. doi: 10.1016/j.jplph.2010.06.003

Pearce, G., Bhattacharya, R., Chen, Y. C., Barona, G., Yamaguchi, Y., and Ryan, C. A. (2009). Isolation and characterization of hydroxyproline-rich glycopeptide signals in black nightshade leaves. Plant Physiol. 150, 1422-1433. doi: 10.1104/pp.109.138669

Pearce, G., Moura, D. S., Stratmann, J., and Ryan, C. A. (2001). Production of multiple plant hormones from a single polyprotein precursor. Nature 411, 817 820. doi: $10.1038 / 35081107$

Pearce, G., and Ryan, C. A. (2003). Systemic signaling in tomato plants for defense against herbivores. Isolation and characterization of three novel defense-signaling glycopeptide hormones coded in a single precursor gene. J. Biol. Chem. 278, 30044-30050. doi: 10.1074/jbc.M304159200

Pearce, G., Siems, W. F., Bhattacharya, R., Chen, Y. C., and Ryan, C. A. (2007). Three hydroxyproline-rich glycopeptides derived from a single petunia polyprotein precursor activate defensin I, a pathogen defense response gene. J. Biol. Chem. 282, 17777-17784. doi: 10.1074/jbc.M701543200

Peña-Cortés, H., Fisahn, J., and Willmitzer, L. (1995). Signals involved in woundinduced proteinase inhibitor II gene expression in tomato and potato plants. Proc. Natl. Acad. Sci. U.S.A. 92, 4106-4113. doi: 10.1073/pnas.92.10.4106

Proels, R. K., Oberhollenzer, K., Pathuri, I. P., Hensel, G., Kumlehn, J., and Huckelhoven, R. (2010). RBOHF2 of barley is required for normal development of penetration resistance to the parasitic fungus Blumeria graminis $\mathrm{f}$. sp. hordei. Mol. Plant Microbe Interact. 23, 1143-1150. doi: 10.1094/MPMI-23-9-1143

Raiola, A., Lionetti, V., Elmaghraby, I., Immerzeel, P., Mellerowicz, E. J., Salvi, G., et al. (2011). Pectin methylesterase is induced in Arabidopsis upon infection and is necessary for a successful colonization by necrotrophic pathogens. Mol. Plant Microbe Interact. 24, 432-440. doi: 10.1094/MPMI-07-10-0157

Rasul, S., Dubreuil-Maurizi, C., Lamotte, O., Koen, E., Poinssot, B., Alcaraz, G., et al. (2012). Nitric oxide production mediates oligogalacturonide-triggered immunity and resistance to Botrytis cinerea in Arabidopsis thaliana. Plant Cell Environ. 35 1483-1499. doi: 10.1111/j.1365-3040.2012.02505.x

Reddy, A. S., Ali, G. S., Celesnik, H., and Day, I. S. (2011). Coping with stresses: roles of calcium- and calcium/calmodulin-regulated gene expression. Plant Cell 23, 2010-2032. doi: 10.1105/tpc.111.084988

Rehrig, E. M., Appel, H., Jones, A. D., and Schultz, C. J. (2014). Roles for jasmonateand ethylene-induced transcription factors in the ability of Arabidopsis to respond differentially to damage caused by two insect herbivores. Front. Plant Sci. 5:407. doi: 10.3389/fpls.2014.00407

Reymond, P., Weber, H., Damond, M., and Farmer, E. E. (2000). Differential gene expression in response to mechanical wounding and insect feeding in Arabidopsis. Plant Cell 12, 707-720. doi: 10.1105/tpc.12.5.707

Riederer, M., and Schreiber, L. (2001). Protecting against water loss: analysis of the barrier properties of plant cuticles. J. Exp. Bot. 52, 2023-2032. doi: 10.1093/jexbot/52.363.2023

Roberts, K. (1992). Potential awareness of plants. Nature 360, 14-15. doi: 10.1038/360014a0

Rodriguez, M. C., Petersen, M., and Mundy, J. (2010). Mitogen-activated protein kinase signaling in plants. Annu. Rev. Plant Biol. 61, 621-649. doi: 10.1146/annurev-arplant-042809-112252

Ryan, C. A., and Jagendorf, A. (1995). Self defense by plants. Proc. Natl. Acad. Sci. U.S.A. 92:4075. doi: 10.1073/pnas.92.10.4075

Sanders, D., Pelloux, J., Brownlee, C., and Harper, J. F. (2002). Calcium at the crossroads of signaling. Plant Cell 14, S401-S417. doi: 10.1105/tpc.002899

Savatin, D. V., Ferrari, S., Sicilia, F., and De Lorenzo, G. (2011). Oligogalacturonideauxin antagonism does not require posttranscriptional gene silencing or stabilization of auxin response repressors in Arabidopsis. Plant Physiol. 157, 1163-1174. doi: 10.1104/pp.111.184663

Savatin, D. V., Gigli, B. N., Marti, L., Fabbri, C., Cervone, F., and De Lorenzo, G. (2014). The Arabidopsis NPK1-related protein kinases ANPs are required for elicitor-induced oxidative burst and immunity. Plant Physiol. 165, 1188-1202. doi: 10.1104/pp.114.236901

Schaller, A., and Stintzi, A. (2009). Enzymes in jasmonate biosynthesis - structure, function, regulation. Phytochemistry 70, 1532-1538. doi: 10.1016/j.phytochem.2009.07.032

Scheer, J. M., and Ryan, C. A. (1999). A 160-kD systemin receptor on the surface of Lycopersicon peruvianum suspension-cultured cells. Plant Cell 11, 1525-1535. doi: 10.1105/tpc.11.8.1525

Schilmiller, A. L., and Howe, G. A. (2005). Systemic signaling in the wound response. Curr. Opin. Plant Biol. 8, 369-377. doi: 10.1016/j.pbi.2005.05.008

Schweighofer, A., Kazanaviciute, V., Scheikl, E., Teige, M., Doczi, R., Hirt, H., et al. (2007). The PP2C-type phosphatase AP2C1, which negatively regulates MPK4 and MPK6, modulates innate immunity, jasmonic acid, and ethylene levels in Arabidopsis. Plant Cell 19, 2213-2224. doi: 10.1105/tpc.106.049585

Schweizer, P., Felix, G., Buchala, A., Müller, C., and Métraux, J. P. (1996a). Perception of free cutin monomers by plant cells. Plant J. 10, 331-341. doi: 10.1046/j.1365313X.1996.10020331.x

Schweizer, P., Jeanguenat, A., Whitacre, D., Metraux, J. P., and Mosinge, E. (1996b). Induction of resistance in barley against Erysiphe graminis f.sp. hordei by free cutin monomers. Physiol. Mol. Plant Pathol. 49, 103-120. doi: 10.1006/pmpp. 1996.0043

Schweizer, P., Jeanguenat, A., Mosinger, E., and Metraux, J. P. (1994). Plant protection by free cutin monomers in two cereal pathosystems. Adv. Mol. Gen. Plant Microbe Interact. 21, 371-374. doi: 10.1007/978-94-011-0177-6_55

Seo, S., Katou, S., Seto, H., Gomi, K., and Ohashi, Y. (2007). The mitogenactivated protein kinases WIPK and SIPK regulate the levels of jasmonic and salicylic acids in wounded tobacco plants. Plant J. 49, 899-909. doi: 10.1111/j.1365-313X.2006.03003.x

Seo, S., Okamoto, N., Seto, H., Ishizuka, K., Sano, H., and Ohashi, Y. (1995). Tobacco MAP kinase: a possible mediator in wound signal transduction pathways. Science 270, 1988-1992. doi: 10.1126/science.270.5244.1988

Sieber, P., Schorderet, M., Ryser, U., Buchala, A., Kolattukudy, P., Metraux, J. P., et al. (2000). Transgenic Arabidopsis plants expressing a fungal cutinase show alterations in the structure and properties of the cuticle and postgenital organ fusions. Plant Cell 12, 721-737. doi: 10.1105/tpc.12.5.721

Staswick, P. E., and Tiryaki, I. (2004). The oxylipin signal jasmonic acid is activated by an enzyme that conjugates it to isoleucine in Arabidopsis. Plant Cell 16, 21172127. doi: $10.1105 /$ tpc.104.023549

Stenzel, I., Hause, B., Maucher, H., Pitzschke, A., Miersch, O., Ziegler, J., et al. (2003). Allene oxide cyclase dependence of the wound response and vascular bundle-specific generation of jasmonates in tomato - amplification in wound signalling. Plant J. 33, 577-589. doi: 10.1046/j.1365-313X.2003.01647.x

Suzuki, N., and Mittler, R. (2012). Reactive oxygen species-dependent wound responses in animals and plants. Free Radic. Biol. Med. 53, 2269-2276. doi: 10.1016/j.freeradbiomed.2012.10.538

Szczegielniak, J., Borkiewicz, L., Szurmak, B., Lewandowska-Gnatowska, E., Statkiewicz, M., Klimecka, M., et al. (2012). Maize calcium-dependent protein kinase (ZmCPK11): local and systemic response to wounding, regulation by touch and components of jasmonate signaling. Physiol. Plant. 146, 1-14. doi: 10.1111/j.1399-3054.2012.01587.x

Takabatake, R., Seo, S., Ito, N., Gotoh, Y., Mitsuhara, I., and Ohashi, Y. (2006). Involvement of wound-induced receptor-like protein kinase in wound signal transduction in tobacco plants. Plant J. 47, 249-257. doi: 10.1111/j.1365313X.2006.02781.X

Takeda, S., Gapper, C., Kaya, H., Bell, E., Kuchitsu, K., and Dolan, L. (2008). Local positive feedback regulation determines cell shape in root hair cells. Science 319, 1241-1244. doi: 10.1126/science. 1152505

Taurino, M., Abelenda, J. A., Rio-Alvarez, I., Navarro, C., Vicedo, B., Farmaki, T., et al. (2014). Jasmonate-dependent modifications of the pectin matrix during potato development function as a defense mechanism targeted by Dickeya dadantii virulence factors. Plant J. 77, 418-429. doi: 10.1111/tpj.12393

Tisi, A., Angelini, R., and Cona, A. (2008). Wound healing in plants: cooperation of copper amine oxidase and flavin-containing polyamine oxidase. Plant Signal. Behav. 3, 204-206. doi: 10.4161/psb.3.3.5372 
Toufighi, K., Brady, S. M., Austin, R., Ly, E., and Provart, N. J. (2005). The Botany array resource: e-northerns, expression angling, and promoter analyses. Plant J. 43, 153-163. doi: 10.1111/j.1365-313X.2005.02437.x

Verica, J. A., Chae, L., Tong, H. Y., Ingmire, P., and He, Z. H. (2003). Tissuespecific and developmentally regulated expression of a cluster of tandemly arrayed cell wall-associated kinase-like kinase genes in Arabidopsis. Plant Physiol. 133 1732-1746. doi: 10.1104/pp.103.028530

Wagner, T. A., and Kohorn, B. D. (2001). Wall-Associated kinases are expressed throughout plant development and are required for cell expansion. Plant Cell 13, 303-318. doi: 10.1105/tpc.13.2.303

Wang, L., Tsuda, K., Sato, M., Cohen, J. D., Katagiri, F., Glazebrook, J., et al. (2009). Arabidopsis CaM binding protein CBP60g contributes to MAMP-induced SA accumulation and is involved in disease resistance against. PLoS Pathog. 5:e1000301. doi: 10.1371/journal.ppat.1000301

Wildon, D. C., Thain, J. F., Minchin, P. E. H., Gubb, I. R., Reilly, A. J., Skipper, Y. D., et al. (1992). Electrical signaling and systemic proteinase inhibitor induction in the wounded plant. Nature 360, 62-65. doi: 10.1038/360062a0

Wolf, S., Hematy, K., and Hofte, H. (2012). Growth control and cell wall signaling in plants. Annu. Rev. Plant Biol. 63, 381-407. doi: 10.1146/annurev-arplant-042811105449

Yamaguchi, Y., Huffaker, A., Bryan, A. C., Tax, F. E., and Ryan, C. A. (2010). PEPR2 is a second receptor for the Pep1 and Pep2 peptides and contributes to defense responses in Arabidopsis. Plant Cell 22, 508-522. doi: 10.1105/tpc.109.068874

Yamaguchi, Y., Pearce, G., and Ryan, C. A. (2006). The cell surface leucine-rich repeat receptor for AtPEP1, an endogenous peptide elicitor in Arabidopsis, is functional in transgenic tobacco cells. Proc. Natl. Acad. Sci. U.S.A. 103, 10104-10109. doi: 10.1073/pnas.0603729103

Yamanaka, T., Nakagawa, Y., Mori, K., Nakano, M., Imamura, T., Kataoka, H., etal. (2010). MCA1 and MCA2 that mediate $\mathrm{Ca}^{2+}$ uptake have distinct and overlapping roles in Arabidopsis. Plant Physiol. 152, 1284-1296. doi: 10.1104/pp.109.147371

Yang, D. H., Hettenhausen, C., Baldwin, I. T., and Wu, J. (2012). Silencing Nicotiana attenuata calcium-dependent protein kinases, CDPK4 and CDPK5, strongly upregulates wound- and herbivory-induced jasmonic acid accumulations. Plant Physiol. 159, 1591-1607. doi: 10.1104/pp.112.199018
Zhang, S. Q., and Klessig, D. F. (1998a). The tobacco wounding-activated mitogenactivated protein kinase is encoded by SIPK. Proc. Natl. Acad. Sci. U.S.A. 95, 7225-7230. doi: 10.1073/pnas.95.12.7225

Zhang, S. Q., and Klessig, D. F. (1998b). Resistance gene N-mediated de novo synthesis and activation of a tobacco mitogen-activated protein kinase by tobacco mosaic virus infection. Proc. Natl. Acad. Sci. U.S.A. 95, 7433-7438. doi: $10.1073 /$ pnas.95.13.7433

Zimmermann, M. R., Maischak, H., Mithofer, A., Boland, W., and Felle, H. H. (2009). System potentials, a novel electrical long-distance apoplastic signal in plants, induced by wounding. Plant Physiol. 149, 1593-1600. doi: 10.1104/pp.108.133884

Zipfel, C., Kunze, G., Chinchilla, D., Caniard, A., Jones, J. D. G., Boller, T., etal. (2006). Perception of the bacterial PAMP EF-Tu by the receptor EFR restricts Agrobacterium-mediated transformation. Cell 125, 749-760. doi: 10.1016/j.cell.2006.03.037

Zipfel, C., Robatzek, S., Navarro, L., Oakeley, E. J., Jones, J. D., Felix, G., et al. (2004). Bacterial disease resistance in Arabidopsis through flagellin perception. Nature 428, 764-767. doi: 10.1038/nature02485

Conflict of Interest Statement: The authors declare that the research was conducted in the absence of any commercial or financial relationships that could be construed as a potential conflict of interest.

Received: 24 July 2014; accepted: 28 August 2014; published online: 16 September 2014 Citation: Savatin DV, Gramegna G, Modesti V and Cervone F (2014) Wounding in the plant tissue: the defense of a dangerous passage. Front. Plant Sci. 5:470. doi: 10.3389/fpls.2014.00470

This article was submitted to Plant-Microbe Interaction, a section of the journal Frontiers in Plant Science.

Copyright (C) 2014 Savatin, Gramegna, Modesti and Cervone. This is an open-access article distributed under the terms of the Creative Commons Attribution License (CC BY). The use, distribution or reproduction in other forums is permitted, provided the original author(s) or licensor are credited and that the original publication in this journal is cited, in accordance with accepted academic practice. No use, distribution or reproduction is permitted which does not comply with these terms. 